\title{
Causality Analysis on Export and Economic Growth Nexus in Ghana
}

\author{
Alice Constance Mensah ${ }^{1 *}$, Ebenezer Okyere ${ }^{2}$ \\ ${ }^{1}$ Mathematics and Statistics Department, Accra Technical University, Accra, Ghana \\ ${ }^{2}$ Ebenezer Okyere, Research and Policy, Banking Supervision Department, Bank of Ghana, Accra, Ghana \\ Email: *alicecabakah@yahoo.com, e_okyere@yahoo.co.uk
}

How to cite this paper: Mensah, A.C. and Okyere, E. (2020) Causality Analysis on Export and Economic Growth Nexus in Ghana. Open Journal of Statistics, 10, 872-888. https://doi.org/10.4236/ojs.2020.105051

Received: September 14, 2020

Accepted: October 27, 2020

Published: October 30, 2020

Copyright $\odot 2020$ by author(s) and Scientific Research Publishing Inc. This work is licensed under the Creative Commons Attribution International License (CC BY 4.0).

http://creativecommons.org/licenses/by/4.0/ (c) (i) Open Access

\begin{abstract}
The study examined the causal relationship between export and economic growth based on monthly data for the period 2010 to 2019. Composite Index Economic Activity (CIEA) was used as a proxy for real GDP (economic growth). Time series econometric techniques were employed to explore long-run and short run relationships as well as the causality between them. The results revealed the existence of long-run relationships; evidence of bi-directional causality and a rapid adjustment to equilibrium between real GDP and exports. Recommendations are that, policy makers should focus on implementing export oriented policies and promote economic growth to achieve sustainable development.
\end{abstract}

\section{Keywords}

Export, Economic Growth, CIEA, Econometric Techniques, GDP

\section{Introduction}

The study takes another look at an age-old debate, "the export and economic growth nexus". This debate has its source in literature since the 1970s with a large number of empirical studies conducted using either annual time series data or cross-section data. These studies on the relationship between exports and economic growth were carried out with annual export data and annual data on Gross Domestic Product (GDP) or annual economic growth rate, [1]-[8]. There are other studies which argued that there exists causality between exports and economic growth using annual data, [9]-[16]. Only a few of the studies used quarterly data set for analyzing the relationship between exports and economic growth [17] [18] [19] [20]. This has necessitated this study.

Economic growth is usually used as a yardstick in gauging economic perfor- 
mance. This has driven many nations in search of dynamic economic policies aimed at boosting their Gross Domestic Product (GDP) levels in achieving economic growth. Gross Domestic Product (GDP) is only available as a quarterly frequency, hence extra variables are necessary to establish a monthly chronology. The study adopted the Composite Index Economic Activity (CIEA) as proxy for monthly real GDP. The CIEA is a single summary statistic that tracks the current state of the economy [21]. It helps to provide useful information that informs researchers in identifying when the economy is in an expansionary phase of the business cycle. The CIEA is less mentioned as compared to its more well-known counterpart, the GDP. The CIEA is a Bank of Ghana (BoG) product and it tracks the GDP very closely and is taken by the BoG as a very good indicator of business confidence. The idea is to construct a group of high frequency indicators that closely track the overall GDP [22].

The primary purpose of this study is to reexamine both the short and long run relationship and causality between exports and economic growth using monthly data set of Ghana. As a contribution to literature, this study used CIEA as a proxy of monthly real GDP and economic growth. The study aims also to help bridge the empirical knowledge gap by examining the relationship between export and economic growth in isolation rather than as part of a bloc of sub-Saharan African countries or developing countries. The results will be helpful for policy-makers since it is the existence of a long-run association between these two variables that may guarantee sustainable economic development.

\section{Literature Review}

There are a number of studies which have been carried out to find the relationship between economic growth and exports using annual data. Some studies have shown that export has increased economic growth. On the other hand, some studies have shown little evidence to prove strong relationship between exports and economic growth.

For instance, studies done by Ram [23] [24] used OLS regression on annual time series data for several developed and developing countries to examine the export-growth relationship. The results indicated a strong positive relationship between exports and economic growth in all these countries.

Afxentiou and Serletis [25], used Vector Autoregressive (VAR) models to test the export-economic growth hypothesis on 16 rich countries of Western Europe, Asia and North America for the period 1950 to 1980 using annual data. The study indicated support for the export led growth hypothesis for USA and Norway while the rest, exports showed negligible or no impact on the level of GDP. The causality direction run from exports to economic growth for USA and Norway, but Granger causality tests for the rest of the countries were uncertain.

A study in Brazil examined the relationship between export and growth for the period 1960-2017 using annual data and found a bi-directional causality in the long run and export-led economic growth in the short run [15]. Another vi- 
tal study carried out tested the validity of the exports led growth hypothesis on 21 sub-Saharan African countries [26]. Exports were found to have a positive and significant effect on economic growth in all the 21 countries. The Granger causality tests however gave mixed results, some of the countries showed evidence of unidirectional causation running from exports to economic growth, others showed evidence of either bi-directional causation and others also showed causation running from economic growth to exports.

Besides, in another comprehensive study by Medina-Smith [27] in Costa Rica, Granger Causality, Cointegration and Durbin-Watson tests were employed on annual time series data covering the period 1950 to 1997. Results revealed strong evidence in support of the export-growth nexus but also that the direction of casualty run from exports to GDP growth. For Botswana, Sentsho [28] concluded that real exports have a positive impact on economic growth. Eusuf and Ahmed [10] studied the causality between export and growth in south Asian countries and made use of annual time series data from IMF's International Financial Statistics. The study did not find any conclusive evidence in favour of export led growth for South Asian Countries.

Hailegiorgis [13] analyzed the Ethiopian economy's export and economic growth relationship using annual data for the period 1974 to 2009. Granger causality test was applied to the data and the result indicates an evidence of uni-directional causality between export and economic growth for Ethiopia

On the contrary, study carried out by Jung and Marshall [9], using Engle-Granger tests and regression techniques on annual time series data to establish the cogency of export led growth in 37 countries around the world revealed a notable lack of evidence in favour of the export-growth nexus. Likewise, Helleiner [29] selected annual time series data from1960 to 1980 of sampled sub-Sahara African countries for a study. The end result of the study was a negative and statistically insignificant effect of export on level of GDP.

Similar to the study of Helleiner [29], Fosu [30] also sampled data from 65 Low developing Countries from the period 1960 to 1980. He adopted a neoclassical economic framework and showed that slower growth is seen in countries which had exports as one of the inputs in their production process than those who did not. Implying export has a weak effect on GDP.

An empirical research carried out by Kibria and Hossain [31] was mainly to examine the causality between export and economic growth of Bangladesh using time series data of 39 observations during 1980-2018. The study also found a bi-directional causal relationship between export and economic growth.

Bahmani-Oskooee and Alse [17], employed quarterly data to study the relationship between exports growth and GDP growth for nine countries. The findings of the study showed a strong empirical support for two-way causality between exports growth and GDP growth for eight countries out of nine.

Another study in Turkey, used quarterly data from 1980 to 2004 to analyse the dynamic relationship between export growth and economic growth. The empir- 
ical research conducted showed a long term Granger causality exists from economic growth to export growth. Again error correction analysis confirms bi-directional short run relationship [19]. In 2020, a similar study was carried out in Turkey to investigate exports and economic growth causality using seasonally adjusted quarterly data of economic growth (real GDP) rate and exports for the period 1987 to 2018. The standard Granger causality test indicates one direction causality that running from exports to real GDP [20].

Additional study that used quarterly data, was by Lee and Huang [18]. The study investigated the causal relationships between export growth and output growth for five East Asian countries. With the help of two-regime multivariate threshold autoregressive approach, there was evidence of export led growth for four of the countries with the exception of Hong Kong.

There are other studies proposing a reverse relationship to the export led hypothesis, that is, economic growth induces trade flows. According to Bhagwati [32] economic growth leads to export expansion since when a country achieves high and sustained growth in output, it will lead to an expansion of that country's exports. Krugman [33] believes that, economic growth leads to expansion of skills and technology which increases the efficiency in production of output and this accelerates exports of the country.

In Tanzania Dimoso and Utonga [34] explored the causal relationship between exports and economic growth by analyzing annual time series data from 1980 to 2015 . The causality test results showed the existence of causality which runs from economic growth to exports.

New insights into export-growth nexus, have been undertaken by Adebayo [8] to shed more light on this interaction by utilizing yearly data spanning between 1981 and 2018 in Nigeria. The study utilized the Toda Yamamoto causality test and found a bi-directional causality between GDP growth and export.

Ascertaining the direction of causation is important for policy connotations in developing strategies. For Ghana, Attah [2], empirically investigated the causal relation between Gross National Product (GNP) and export growth for Ghana using annual data from 1960 to 1992 applied several econometric tests including Granger causality test. At the end of the study, a unidirectional causality between the growth rate of real GNP and real exports was established.

Twumasi-Ankrah and Wiah [35] explored the causal influence of export earnings of cocoa towards economic growth using annual data from 1980 to 2011. The study revealed a bi-directional causality from export earnings to economic growth (GDP).

An empirical research by Owusu [36] examined the relationship between real export revenue and non-export GDP within the context of the Ghanaian economy from 1970 to 2015. To investigate a causal relationship between the two variables, the study employed the autoregressive distributed lag (ARDL)-bounds approach of co-integration and unrestricted error correction model. The result found a bi-directional relationship between real export revenue and non-export 
GDP.

Tuffour [11], researched on the topic export-led growth hypothesis a causality analysis of Ghana and utilized annual time series data for the period 1970 to 2008 by applying vector error correction Granger causality methodology. The findings were that export-led growth hypothesis is not supported in the short run were not supported but somewhat Growth-led export.

In 2015, Tetteh [7], investigated the relationship between exports and economic growth in Ghana. Annual data for the period 1980 to 2013 was used and applying time series econometric techniques of cointegration and vector error correction estimation, the findings were evidence of long run relationships between the variables and also bi-directional causality between exports and GDP growth using Granger causality test.

\section{Materials and Methodology}

The object of the study is to explore the dynamics of the relationship between exports and economic growth in Ghana using the monthly data for the period 2011 to 2019. The variables used in this study were total exports and economic growth. Total exports (EXP), approximates the total value of goods and services made in Ghana but sold abroad, while Composite Index Economic Activity (CIEA) approximates monthly real GDP which was used as a proxy for economic growth. The data for the study was obtained from Bank of Ghana.

Cointegration and error correction modelling techniques were the estimation methodology employed. The estimation procedure is as follows: unit root test, cointegration test and the error correction model estimation.

\subsection{Unit Root Test}

Macroeconomic time series is susceptible to non stationarity which causes regression results to suffer from spurious regression problem [37]. To avert this possibility the variables are tested for stationarity. An initial step involved transforming all the variables into natural logarithm in order to lessen the probability of hetroskedasticity in the model. The univariate properties of all data series are then determined to ascertain their degree of integration using the Augmented Dickey-Fuller (ADF) test based on the null hypothesis that each variable has a unit root. This consist of running a regression of the first difference of the series against the series lagged once, lagged difference terms and optionally, a constant a time trend. This can be expressed as follows:

$$
\Delta Y_{t}=\alpha_{0}+\alpha_{1} t+\alpha_{2} Y_{t-1}+\sum_{j=1}^{p} \alpha_{j} \Delta Y_{t-j}+\varepsilon_{t}
$$

The ADF procedure, test for a unit root is conducted on the coefficient of $Y_{t-1}$ in the regression. If the coefficient is significantly different from zero, then the hypothesis that $Y_{t}$ contains a unit root is rejected. The rejection of the null hypothesis implies stationarity. The null hypothesis is that the $Y_{t}$ is a non-stationary series $\equiv \mathrm{H}_{0}: \alpha_{2}=0$ with the alternative being $\mathrm{H}_{\alpha}: \alpha_{2}<0$. 
If the calculated value of ADF statistics is higher than McKinnon's critical values, then the null hypothesis $\left(\mathrm{H}_{0}\right)$ is not rejected and the series is non-stationary or not integrated of order zero, $\mathrm{I}(0)$. Failure to reject the null hypothesis leads to conducting the test on the difference of the series, so further differencing is conducted until stationary is reached and the null hypothesis is rejected. If the time series (variables) are non-stationary in their levels, they can be integrated with $\mathrm{I}(1)$, when their first differences are stationary.

\subsection{Cointegration Test}

Engle and Granger [38] and Johansen, [39] used the cointegration test to determine the presence of potential long-run equilibrium relationship and this is applied in the study. The Johansen method applies the maximum likelihood procedure to determine the presence of cointegrated vectors in non-stationary time series.

In the Johansen framework, the first step is the estimation of an unrestricted, closed $p^{\text {th }}$ order VAR in $k$ variables. The VAR model as considered in this study is:

$$
Y_{t}=A_{1} Y_{t-1}+A_{2} Y_{t-2}+\cdots+A_{p} Y_{t-p}+B X_{t}+\varepsilon_{t}
$$

where $Y_{t}$ is a $k$-vector of non-stationary $\mathrm{I}(1)$ endogenous variables, $X_{t}$ is a $d$-vector of exogenous deterministic variables, $A_{1}, \cdots, A_{p}$ and $B$ are matrices of coefficients to be estimated, and $\varepsilon_{t}$ is a vector of innovations that may be contemporaneously correlated but are uncorrelated with their own lagged values and uncorrelatd with all of the right-hand side variables.

The stated VAR model is generally estimated in its first-difference form as:

$$
\Delta Y_{t}=\Pi Y_{t-1}+\sum_{i=1}^{p-1} \Gamma_{i} \Delta Y_{t-i}+B X_{t}+\varepsilon_{t}
$$

where, $\Pi=\sum_{i-1}^{p} A_{i}-I$, and $\Gamma_{i}=-\sum_{j=i+1}^{p} A_{j}$

The Johansen approach to cointegration test is based on two test statistics, namely, the trace test statistic and the maximum eigenvalue test statistic.

\subsubsection{The trace Test Statistic}

The trade test statistics can be specified as: $\tau_{\text {trace }}=-T \sum_{i=r+1}^{k} \log \left(1-\lambda_{i}\right)$, where $\lambda_{i}$ is the $i^{\text {th }}$ largest eigenvalue of matrix $\Pi$ and $T$ is the number of observations. In the trace test, the null hypothesis is that the number of distinct cointegration vector(s) is less than or equal to the number of cointegration relations $(r)$.

\subsubsection{Maximum Eigenvalue Test}

The maximum eigenvalue test examines the null hypothesis of exactly $r$ cointegrating relations against the alternative of $r+1$ cointegrating relations with the test statistics:

$\tau_{\max }=-T \log \left(1-\lambda_{r+1}\right)$, where $\lambda_{r+1}$ is the $(r+1)^{\text {th }}$ largest squared eigenvalue. In the trace test, the null hypothesis of $r=0$ is tested against the alternative of $r+$ 1 cointegrating vectors. 


\subsection{Vector Error Correction Model (VECM)}

The general form of the VECM is as follows:

$$
\begin{aligned}
& \Delta X_{t}=\alpha_{0}+\lambda_{1} E C_{t-1}^{1}+\sum_{i=1}^{m} \alpha_{i} \Delta X_{t-i}+\sum_{j=1}^{n} \alpha_{j} \Delta Y_{t-j}+\varepsilon_{1 t} \\
& \Delta Y_{t}=\beta_{0}+\lambda_{2} E C_{t-1}^{2}+\sum_{i=1}^{m} \beta_{i} \Delta Y_{t-i}+\sum_{j=1}^{n} \beta_{j} \Delta X_{t-j}+\varepsilon_{2 t}
\end{aligned}
$$

where $\Delta$ is the first difference operator, $E C_{t-1}$ is the error correction term lagged one period; $\lambda$ is the short-run coefficient of the error correction term $(-1$ $<\lambda<0$ ); and $\varepsilon$ is the white noise. The error correction coefficient $(\lambda)$ is very important in this error correction estimation as the greater coefficient indicates higher speed of adjustment of the model from the short-run to the long-run.

The error correction term represents the long run relationship. A negative and significant coefficient of the error correction term indicates the presence of long-run causal relationship. If both the coefficients of error correction terms in both the equations are significant, this will suggest the bi-directional causality. If only $\lambda_{1}$ is a negative and significant, this will suggest a unidirectional causality from $Y$ to $X$ (GDP to exports), implying that GDP drives exports towards long-run equilibrium, but not the other way around. Similarly, if $\lambda_{2}$ is negative and significant, this will suggest a unidirectional causality from $X$ to $Y$ (exports to GDP), implying that exports drives GDP towards long-run equilibrium but not the other way around. On the other hand, the lagged terms of $\Delta X_{i}$ and $\Delta Y_{i}$ appeared as explanatory variables, indicating a short-run cause and effect relationship between the two variables. Thus, if the lagged coefficients of $\Delta X_{i}$ appear to be significant in the regression of $\Delta Y_{i}$, this will mean that $X$ causes $Y$. Similarly, if the lagged coefficients of $\Delta Y_{i}$ appear to be significant in the regression of $\Delta X_{i}$ this will mean that $Y$ causes $X$.

\subsection{Causality Test}

A number of arguments have been put forward by different studies concerning the potential contribution of exports to economic growth. To solve this complex issue, the study uses the methodology proposed by Granger. Testing for causality between exports and economic growth in the granger sense involves, whether lagged information on economic growth provides any statistically significant information about export in the presence of lagged exports. If not, then economic growth does not Granger-cause exports. A simple Granger causality test involving two variables, exports and GDP can therefore be specified as:

$$
\begin{aligned}
\operatorname{lGDP}_{t} & =\alpha_{0}+\sum_{j=1}^{p} \alpha_{j} \operatorname{lGDP}_{t-j}+\sum_{j=1}^{q} \beta_{j} \operatorname{lEX}_{t-j}+\varepsilon_{t} \\
\operatorname{lEX} & =b_{0}+\sum_{j=1}^{p} b_{t} \operatorname{lEX}_{t-j}+\sum_{j=1}^{q} \lambda_{j} \operatorname{lGDP}_{t-j}+v_{t}
\end{aligned}
$$

where, lGDP represents natural log of real gross domestic product (as a measure of economic growth) and IEX represents natural $\log$ of real exports. $\mathcal{E}_{t}$ and $V_{t}$ are 
serially uncorrelated white noise error term; the coefficients $\alpha, \beta, b, \lambda$ are expressing the short-run dynamics of the model's convergence to equilibrium; and $\mathrm{p}$ and $\mathrm{q}$ are lengths for each variable in each equation. The null hypothesis to be tested is:

$\mathrm{H}_{0}: \alpha_{j}=0, j=1, \cdots, q$, Export growth does not cause GDP growth.

$\mathrm{H}_{1}: b_{t}=0, t=1, \cdots, q$, GDP growth does not cause Export growth.

\section{Empirical Analysis}

The analysis of the data and interpretation of the results of the study are presented in Table 1. Thus, findings of stationarity test, cointegration test, and Granger causality test as well as Vector Error Correction model of testing for short-run and long-run causality between exports and GDP are discussed.

\subsection{Test for Unit Root}

The commonly accepted Augmented Dickey-Fuller unit root test was adopted to stationary test of exports and CIEA series. The test results are shown in Table 2 which show that level value of the two sequences is non-stationary. In order to reduce the fluctuations of the data, further test was made on the two sequences which indicated a first order difference. The two new series LNEXP and LCIEA are obtained and their unit root test results are shown in Table 3.

\subsection{Estimation of VAR Model}

The major concern of the VAR model is to determine lag intervals for endogenous. The larger the lag intervals for endogenous is the more it can entirely reflect the dynamic nature of the model. However, more parameters will be needed to be estimated to constantly reduce degrees of freedom of the model. Considering

Table 1. Descriptive statistics.

\begin{tabular}{ccc}
\hline & CIEA & EXPORT \\
\hline Mean & 7.958032 & 1056.313 \\
Median & 6.590669 & 1057.532 \\
Maximum & 25.15602 & 1439.350 \\
Minimum & -5.173353 & 513.5700 \\
Std. Dev. & 5.829357 & 221.4420 \\
Skewness & 0.628178 & -0.255167 \\
Kurtosis & 3.083517 & 2.325697 \\
Jarque-Bera & 7.927023 & 3.575628 \\
Probability & 0.018996 & 0.167326 \\
Sum & 954.9638 & $126,757.5$ \\
Sum Sq. Dev. & 4043.787 & $5,835,350$. \\
Observations & 120 & 120 \\
\hline
\end{tabular}


Table 2. Augmented dickey-fuller test on LCIEA and LNEX. Null hypothesis LCIEA, LNEX has unit root.

\begin{tabular}{cccccc}
\hline Variables & Test Statistics & Critical & Critical & Critical & P-Value \\
\hline & & Value 1\% & Value 5\% & Value 10\% & \\
\hline CIEA & -1.379462 & -2.586753 & -1.943853 & -1.614749 & 0.1551 \\
LNEXP & 0.686152 & -2.584707 & -1.943563 & -1.614927 & 0.8625 \\
\hline
\end{tabular}

Table 3. ADF test on D(CIEA), D(LNEXP). Null hypothesis D(CIEA), D(LNEXP) has a unit root.

\begin{tabular}{cccccc}
\hline Variables & Test Statistics & Critical & Critical & Critical & P-Value \\
\hline & & Value $1 \%$ & Value 5\% & Value 10\% & \\
\hline D(CIEA) & -8.900595 & -2.585226 & -1.943637 & -1.614882 & 0.0000 \\
D(LNEXP) & -14.95897 & -2.584707 & -1.943563 & -1.614927 & 0.0000 \\
\hline
\end{tabular}

selection of lag intervals for endogenous, the study adopted the lowest AIC value as primary concern. It can be deduced from Table 4 that the optimal lag order for the VAR model is 4, the AIC value is small, which indicates that the explanatory ability of the model is very strong.

As shown in Figure 1, all of the inverse root of AR characteristic polynomial is located inside the circle, which means the lag order of 4 is appropriate, and the established VAR model is stable.

\subsection{Cointegration Test}

Cointegration relationship between DCIEA and DEXP has been investigated using the Johansen technique. Table 5 reports on the cointegration test results and both trace statistic and maximum eigenvalue statistic indicate that there is at most one cointegration vector between exports and CIEA at 5\% level of significance. The implication is export and economic growth establishes a long run relationship in Ghana which is corroborated with the work of [6].

Normalized Cointegration Coefficients:

$$
\text { lCIEA }_{t-1}=6.440 \mathrm{lEXP}_{t-1}-0.047
$$

The cointegration equation has been normalized for lCIEA to get a meaning from the coefficients as indicated in Table 6 . As all the variables are logarithmic, the coefficients may be interpreted in terms of elasticity. The equation showed that each percentage point increase in export will cause the increase of 6.440 percentage points in CIEA all things being equal. It is seen that export has a positive impact on economic growth and that increases in primary export revenues also results in expansion of the GDP level and hence growth in the long run. It can then be said that, economic growth elasticity with respect to exports is more elastic. This outcome is consistent with studies by [25] [26] [27]. However, this finding controverts that of [29]. The positive relationship between exports and GDP is also supported by macroeconomic theory which argues that exports are 
Table 4. Results of VAR lag order selection criteria.

\begin{tabular}{ccccccc}
\hline Lag & LogL & LR & FPE & AIC & SC & HQ \\
\hline 1 & -235.4318 & NA & 0.256235 & 4.314086 & $4.411727^{\star}$ & $4.353696^{\star}$ \\
2 & -229.6872 & 11.07523 & 0.248319 & 4.282652 & 4.477933 & 4.361872 \\
3 & -226.7900 & 5.481050 & 0.253341 & 4.302523 & 4.595445 & 4.421353 \\
4 & -221.2978 & $10.19290^{\star}$ & $0.246691^{\star}$ & $4.275635^{\star}$ & 4.666198 & 4.434075 \\
5 & -219.3950 & 3.462594 & 0.256314 & 4.313424 & 4.801628 & 4.511474 \\
6 & -214.1920 & 9.281050 & 0.250998 & 4.291748 & 4.877593 & 4.529408 \\
7 & -210.5568 & 6.353459 & 0.252907 & 4.298321 & 4.981806 & 4.575590 \\
8 & -208.6482 & 3.266962 & 0.262972 & 4.336004 & 5.117130 & 4.652883 \\
\hline
\end{tabular}

${ }^{*}$ indicates lag order selected by the criterion; LR: sequential modified LR test statistic (each test at $5 \%$ level); FPE: Final prediction error; AIC: Akaike information criterion; SC: Schwarz information criterion; HQ: Hannan-Quinn information criterion.

\section{Inverse Roots of AR Characteristic Polynomia}

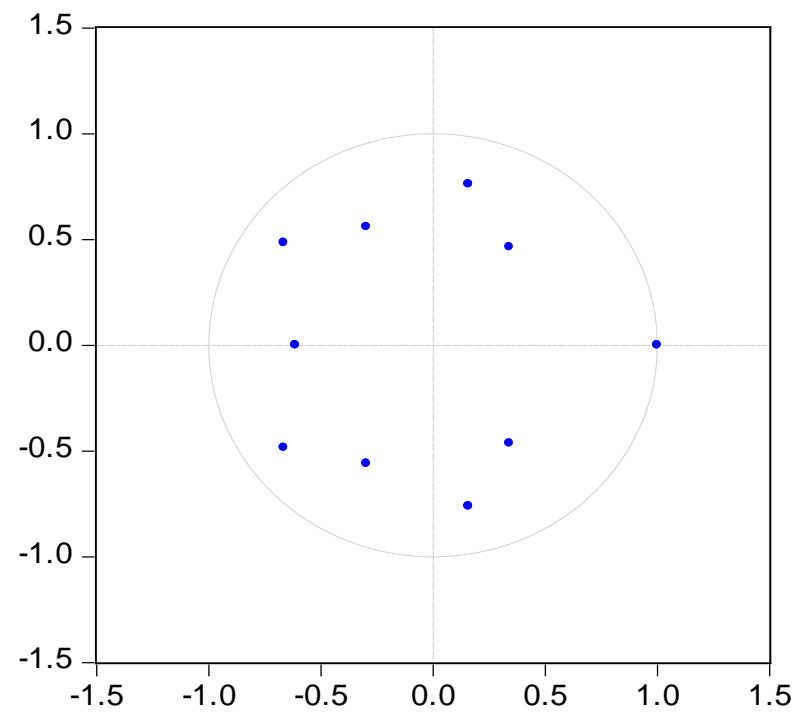

Figure 1. Inverse roots of AR characteristic polynomial.

Table 5. Johansen cointegration test results.

\begin{tabular}{cccccc}
\hline Hypothesized & Eigen & Trace & Critical Value & Maximum & Critical value \\
\hline Number of cointegrating & Value & Statistics & at $5 \%$ & Eigen & at $5 \%$ \\
\hline Equations & & & (p-value) & Statistics & (p-value) \\
\hline None $^{*}$ & 0.276 & 68.455 & $15.495(0.000)$ & 36.815 & $14.265(0.000)$ \\
At most $1^{*}$ & 0.242 & 31.64 & $3.841(0.000)$ & 31.64 & $3.842(0.000)$ \\
\hline
\end{tabular}

injection to the circular flow of income and an increase in their level results in the expansion of the aggregate demand hence national output.

On the premise of the existence of cointegration relationships, Vector error correction model has been established. The error correction coefficient of -2.04 
Table 6. Results of cointegration equation.

\begin{tabular}{|c|c|c|c|}
\hline 1 Cointegrating Equation(s): & & Log likelihood & -244.0608 \\
\hline $\mathrm{D}(\mathrm{CIEA})$ & $\mathrm{D}($ LNEXP) & & \\
\hline \multirow[t]{2}{*}{1.000000} & 6.439905 & & \\
\hline & $(3.79410)$ & & \\
\hline \multirow[t]{2}{*}{$\mathrm{D}(\mathrm{CIEA}, 2)$} & -2.039081 & & \\
\hline & $(0.34079)$ & & \\
\hline \multirow[t]{2}{*}{$\mathrm{D}(\mathrm{LNEXP}, 2)$} & -0.040274 & & \\
\hline & $(0.01264)$ & & \\
\hline
\end{tabular}

implies high speed of adjustment of the model from the short-run to the long run. Again since it is significant and negative, it indicates the presence of long-run causal relationship which bi-directional. Both coefficients of error correction terms are significant and negative so it can be said that, export drives economic growth (CIEA) and vice versa.

From Table 7, the fitting degree of VEC model $\mathrm{R}^{2}>0.5$, and AIC and SC criteria values are relatively small, which indicates the reasonability of the model estimation. The overall fit of 0.722 indicates $72.2 \%$ of the systemic variation in economic growth is explained by the ECM. Again, it can be justified that the lagged variables are jointly significant in explaining the short run variations in economic growth at $5 \%$ significant level $($ F-statistic $=0.000)$.

\subsection{Wald Test of Vector Error Correction Model}

The next step after going through the short run dynamics, is to perform the Wald coefficient test to establish the causality of the independent variable (export) on the dependent variable, CIEA, in the short run. It can be seen from Table 8 that, Wald test was used to test null hypothesis that all lagged values of exports do not jointly cause economic growth.

$$
\begin{aligned}
& \mathrm{H}_{0}: \mathrm{C} 6=\mathrm{C} 7=\mathrm{C} 8=\mathrm{C} 9=0 \\
& \mathrm{H}_{1}: \mathrm{C} 6=\mathrm{C} 7=\mathrm{C} 8=\mathrm{C} 9 \neq 0
\end{aligned}
$$

Where C6, C7, C8 and C9 represents export lagged in first order, export lagged in second order, export lagged in third order and export lagged in fourth order. As indicated in Table 8, the results led to the rejection of the null hypothesis. This means all the lagged values of exports can jointly influence economic growth. Hence, there is a causality running from exports to economic growth in the short-run at $5 \%$ significance level.

\subsection{Diagnostic Tests}

The study examined the adequacy of the specified models with various diagnostic tests including test for serial correlation and normality of residuals. The study used the Cumulative Sum of recursive residuals (CUSUM) test for the serial correlation of the model, which turned out to be stable or valid, see Figure 2. 
Table 7. VEC estimation results and test.

\begin{tabular}{ccccc}
\hline Error Correction & \multicolumn{2}{c}{$\mathrm{D}$ (CIEA) } & \multicolumn{2}{c}{$\mathrm{D}(\mathrm{LNEXP})$} \\
\hline CointEq1 & -2.03908 & {$[-5.98345]$} & -0.04027 & {$[-3.18586]$} \\
$\mathrm{D}(\mathrm{CIEA}(-1))$ & 0.601354 & {$[2.05316]$} & 0.037880 & {$[3.48648]$} \\
$\mathrm{D}(\mathrm{CIEA}(-2))$ & 0.194234 & {$[0.82449]$} & 0.027041 & {$[3.09427]$} \\
$\mathrm{D}(\mathrm{CIEA}(-3))$ & 0.036709 & {$[0.22217]$} & 0.018883 & {$[3.08072]$} \\
D(CIEA(-4)) & -0.14518 & {$[-1.50140]$} & 0.008714 & {$[2.42925]$} \\
$\mathrm{D}($ LNEXP(-1)) & 10.71519 & {$[3.29731]$} & -0.83776 & {$[-6.94963]$} \\
D(LNEXP(-2)) & 9.051741 & {$[2.27158]$} & -0.52147 & {$[-3.52780]$} \\
D(LNEXP(-3)) & 6.354194 & {$[1.66243]$} & -0.27085 & {$[-1.91027]$} \\
D(LNEXP(-4)) & 5.165923 & {$[1.95064]$} & -0.08055 & {$[-0.81997]$} \\
C & 0.084444 & {$[0.23223]$} & 0.000840 & {$[0.06230]$} \\
R-squared & 0.722 & & 0.6114 & \\
Log likelihood & -311.1184 & & 64.42757 & \\
Akaike AIC & 5.633656 & & 0.954870 & \\
Schwarz SC & 5.873673 & & 0.714852 & \\
\hline
\end{tabular}

Table 8. Wald test of VECM (CIEA is the dependent variable).

\begin{tabular}{cccc}
\hline Wald Test: & & & \\
\hline Equation: Untitled & & & \\
\hline Test Statistic & Value & $\mathrm{df}$ & Probability \\
F-statistic & 3.288545 & $(4,104)$ & 0.0140 \\
Chi-square & 13.15418 & 4 & 0.0105 \\
\hline
\end{tabular}

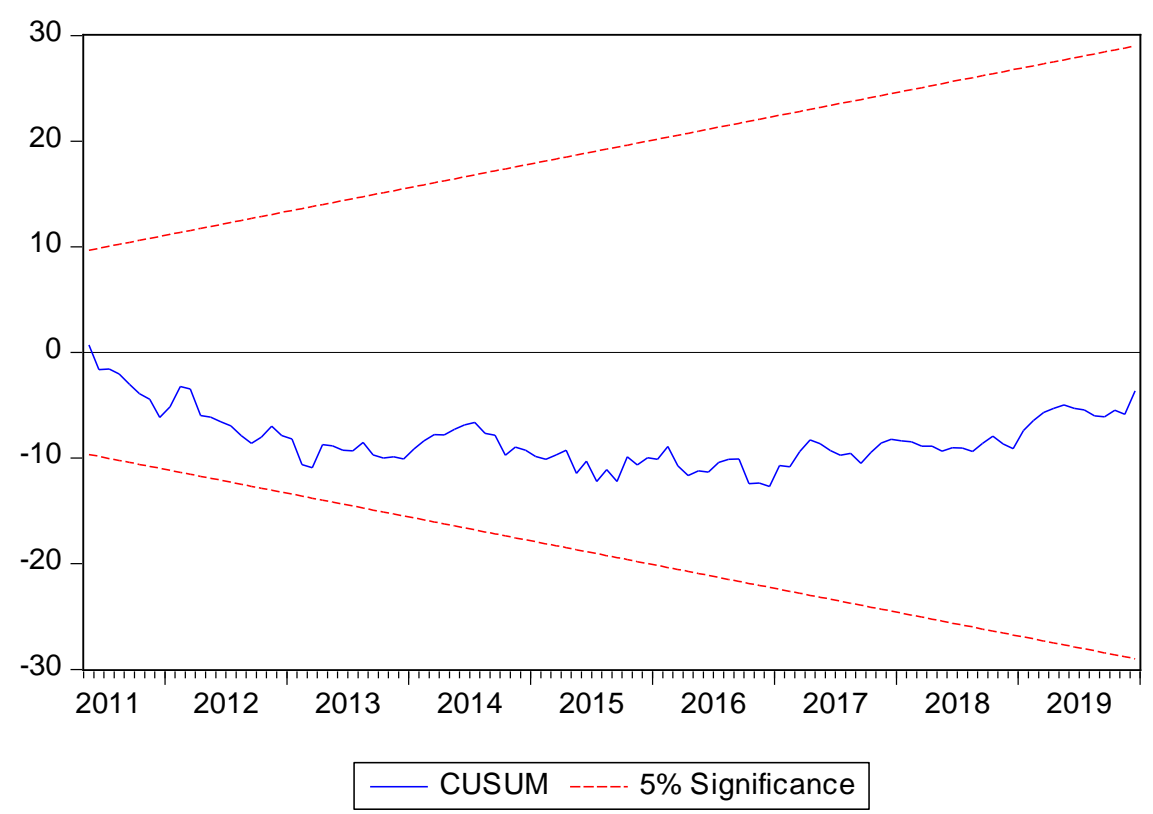

Figure 2. Plot of CUSUM for the estimated ECMs for economic growth and exports. 
The Breusch Godfrey LM test was also applied on the residuals of the model to test for autocorrelation. This tests the null hypothesis of no serial correlation up to lag order 4 for this dataset. From Table 9, it is seen that all the LM probability values are greater than the 5 percent level of significance $(0.05)$ in the model with a lag length of 4 . This leads to the decision of failing to reject the null hypothesis of no serial correlation. This information indicates that the estimated ECM is stable and significant enough for the prior analysis.

Granger causality test was used to further test for the causal relationship between the variables. From Table 10 it can be seen that, the $\mathrm{P}$ value is less than the significant level of $5 \%$ in both cases, which indicate the existence of Granger cause. The result revealed that, export does Granger-cause CIEA (economic growth) and CIEA also granger-cause exports, hence bi-directional. The implication is that growth in exports result in growth in CIEA or past values of exports increase the prediction of CIEA growth. This result supports previous results [35] [36].

The variance decomposition refers to the decomposition of mean square error in to contribution of each variable. Variance decomposition can be applied to determine the dynamic interaction between CIEA (economic growth) and exports. From Table 11, the result of 10 -year period variance decomposition is

Table 9. Breusch-Godfrey serial correlation LM test.

\begin{tabular}{cccc}
\hline F-statistic & 0.761002 & Prob. F $(4,100)$ & 0.5531 \\
Obs $^{\star}$ R-squared & 3.367658 & Prob. Chi-Square(4) & 0.4983 \\
\hline
\end{tabular}

Table 10. Granger causality test.

\begin{tabular}{|c|c|c|c|}
\hline \multicolumn{4}{|c|}{ Dependent variable: D(CIEA) } \\
\hline Excluded & Chi-sq & Df & Prob. \\
\hline $\mathrm{D}(\mathrm{LNEXP})$ & 13.154 & 4 & 0.0105 \\
\hline All & 13.154 & 4 & 0.015 \\
\hline \multicolumn{4}{|c|}{ Dependent variable: D(LNEXP) } \\
\hline Excluded & Chi-sq & $\mathrm{df}$ & Prob. \\
\hline $\mathrm{D}$ (CIEA) & 13.805 & 4 & 0.0079 \\
\hline All & 13.805 & 4 & 0.0079 \\
\hline
\end{tabular}

Table 11. Variance decomposition.

\begin{tabular}{cccc}
\hline \multicolumn{4}{c}{ Variance Decomposition of (CIEA): } \\
\hline Period & S.E & D(CIEA) & D(LNEXP) \\
\hline 1 & 3.820572 & 100 & 0.000000 \\
2 & 4.294618 & 99.97959 & 0.020411 \\
3 & 4.377726 & 99.84830 & 0.151695 \\
4 & 4.396942 & 99.75011 & 0.249890 \\
\hline
\end{tabular}




\section{Continued}

\begin{tabular}{cccc}
\hline 5 & 4.418157 & 99.19380 & 0.806203 \\
6 & 4.495305 & 98.80472 & 1.195278 \\
7 & 4.498760 & 98.80592 & 1.194079 \\
8 & 4.509456 & 98.78660 & 1.213398 \\
9 & 4.511096 & 98.76014 & 1.239855 \\
10 & 4.513052 & 98.70932 & 1.290678 \\
\hline Variance Decomposition 0 (LNEXP): & & $\mathrm{D}(\mathrm{LNEXP})$ \\
\hline Period & $\mathrm{S} . \mathrm{E}$ & $\mathrm{D}(\mathrm{CIEA})$ & 89.76722 \\
\hline 1 & 0.130989 & 10.23278 & 90.66094 \\
2 & 0.137332 & 9.339058 & 89.66101 \\
3 & 0.139016 & 10.33899 & 88.95447 \\
4 & 0.139889 & 11.04553 & 88.55326 \\
5 & 0.140248 & 1.44674 & 88.56629 \\
6 & 0.140331 & 11.43371 & 88.45615 \\
7 & 0.140495 & 11.54385 & 88.35110 \\
8 & 0.140628 & 11.6489 & 88.30712 \\
\hline 0 & 0.140674 & 11.69288 & \\
\hline & 0.140678 & 11.69733 & \\
\hline
\end{tabular}

Cholesky Ordering: D(CIEA) D(LNEXP).

displayed taking the $3^{\text {rd }}$ and the $10^{\text {th }}$ periods as short run and long run period respectively. In the short run shock to CIEA accounts for $99.85 \%$ variation of fluctuation in CIEA that is termed own shock, a shock to export can influence $0.15 \%$ fluctuation in CIEA, which indicates a short run equilibrium between the two variables. On the other hand, in the long run, the impact of shock on export contributes $88.30 \%$ fluctuations in the variation of exports and shock on CIEA contributes $11.70 \%$ variation in the fluctuation in exports.

\section{Conclusions and Recommendation}

The study specifically aimed at empirically investigating the relationship between exports and economic growth in Ghana during the period 2010 to 2019 using monthly data instead of the well-known annual data. Composite Index Economic Activity (CIEA) was used as a proxy for monthly real GDP (economic growth). To fulfil the objectives, specific null hypotheses were tested investigating whether or not exports contribute to economic growth and vice versa. In addition, the study tested for causality between export and economic growth. The study also confirmed the existence of long-run relationship (cointegration) between exports and economic growth, inferring that indeed export led growth is truly a sustainable way of achieving economic development in Ghana in the long run. 
The above findings show that export led growth holds for Ghana, the positive and statistically significant result for exports has important policy implications for the country's economic growth and developmental agenda. The government should also go ahead in implementing the recently launched Planting for export and rural development achieve sustainable development through export promotion. Ghana needs to diversify her export basket in order to sustain her export led growth agenda, promotion of non-traditional goods. There is also the need to embark on value-addition if the agenda is to be successful. This can be done through investing in technologies to help in processing its primary export commodities to boost export quality and revenue. Therefore, the government needs to create a conducive investment climate for foreign direct investment in the export sector.

Another policy option for the government is to consider providing subsidies to export-oriented producers especially Small and Medium scale Enterprises (SMEs) who drive the economy. Additionally, the government should increase the producer prices of her major export commodities such as cocoa.

\section{Research Contribution}

Most of the previous studies fail to utilize monthly data to explore the strength of the causal interaction between exports and economic growth. This paper utilized the composite index economic activity as proxy for monthly real GDP analysis in the case of Ghana. Though empirical estimation of this research is solid by utilizing monthly data estimate, further research is required in other countries using monthly data estimates of other variables that influence economic growth.

\section{Conflicts of Interest}

The authors declare no conflicts of interest regarding the publication of this paper.

\section{References}

[1] Doraisami, A. (1996) Export Growth and Economic Growth: A Re-Examination of Some Time-Series Evidence of the Malaysian Experience. The Journal of Developing Areas, 30, 223-230.

[2] Attah, K.B. (1998) Primary-Export-Led Growth: The Evidence of Ghana. Journal of Economic Development, 23, 176-178.

[3] Ekanayake, E.M. (1999) Exports and Economic Growth in Asian Developing Countries: Cointegration and Error-Correction Models. Journal of Economic Development, 24, 43-56.

[4] Erfani, G.R. (1999) Export and Economic Growth in Developing Countries. International Advances in Economic Research, 5, 147-148. https://doi.org/10.1007/BF02295041

[5] Adu, J. (2011) Non-Traditional Exports and Economic Growth: The Case of Ghana.

[6] Enu, P., Dodzi, E.K.H. and Hagan, E. (2013) The Impact of Foreign Trade on Eco- 
nomic Growth in Ghana (1980-2012). https://doi.org/10.6007/IJAREMS/v2-i5/371

[7] Tetteh, C. (2015) Exports and Economic Growth: The Case of Ghana. Thesis, The University of Ghana, Legon.

[8] Adebayo, T.S. (2020) New Insights into Export-Growth Nexus: Wavelet and Causality Approaches. Asian Journal of Economics, Business and Accounting, 15, 32-44. https://doi.org/10.9734/ajeba/2020/v15i230212

[9] Jung, W.S. and Marshall, P.J. (1985) Exports, Causality, and Growth in Developing Countries. Journal of Development Economics, 18, 1-12. https://doi.org/10.1016/0304-3878(85)90002-1

[10] Eusuf, M.A. and Ahmed, M. (2007) Causality between Export and Growth: Evidence from South Asian Countries. The Jahangir Nagar Economic Review, 19, 73-86.

[11] Tuffour, J.K. (2010) Export-Led Growth Hypothesis: A Causality Analysis of Ghana. International Journal of Economics, 4, 233-247.

[12] Ray, S. (2011) A Causality Analysis on the Empirical Nexus between Exports and Economic Growth: Evidence from India. International Affairs and Global Strategy, 1, 24-39.

[13] Hailegiorgis, B.A. (2012) The Effect of Export-Led Growth Strategy on the Ethiopian Economy. American Journal of Economics, 2, 50-56.

[14] Kalaitzi, A.S. and Cleeve, E. (2017) Export-Led Growth in the UAE: Multivariate Causality between Primary Exports, Manufactured Exports and Economic Growth. Eurasian Business Review, 8, 341-365. https://doi.org/10.1007/s40821-017-0089-1

[15] Dinç, D.T. and Gökmen, A. (2019) Export-Led Economic Growth and the Case of Brazil: An Empirical Research. Journal of Transnational Management, 24, 122-141. https://doi.org/10.1080/15475778.2019.1609895

[16] Okyere, I. (2020) The Impact of Export and Import to Economic Growth of Ghana. European Journal of Business and Management, 12, 130.

[17] Bahmani-Oskooee, M. and Alse, J. (1993) Export Growth and Economic Growth: An Application of Cointegration and Error-Correction Modeling. Journal of Developing Areas, 27, 535-542.

[18] Lee, C. and Huang, B. (2002) The Relationship between Exports and Economic Growth in East Asian Countries: A Multivariate Threshold Autoregressive Approach. Journal of Economic Development, 27, 45-68.

[19] Karagöz, M. and Şen, A. (2005) Elektronik Sosyal Bilimler Dergisi. http://www.e-sosder.com

[20] Yilmaz, A. (2020) Revisit Exports-Growth Nexus in Turkey. Business and Economics Research Journal, 11, 33-50. https://doi.org/10.20409/berj.2020.233

[21] Amoah, B., Abradu-Otoo, P., Blankson, F.F. and Bawumia, M. (2003) Estimating a Composite Leading Indicator of Economic Activity for Ghana. Bank of Ghana Working Paper No. 2003/04.

[22] Anguyo, F.L. (2011) A Model to Estimate a Composite Indicator of Economic Activity (CIEA) for Uganda. Bank of Uganda Working Paper No. 11/11.

[23] Ram, R. (1987) Causality Relationship between Exports and Economic Growth. The Journal of Development Economics, 9, 152-158.

[24] Ram, R. (1985) Exports and Economic Growth: Some Additional Evidence. Economic Development and Cultural Change, 33, 415-425. https://doi.org/10.1086/451468

[25] Afxentiou, P.C. and Serletis, A. (1991) Exports and GNP Causality in the Industrial Countries: 1950-1985. Kyklos, 44, 167-179. 
https://doi.org/10.1111/j.1467-6435.1991.tb02095.x

[26] Njikam, O. (2003) Exports and Economic Growth in Sub-Saharan Africa: Is There a Connection? University of Yaoundé, Yaoundé.

[27] Medina-Smith, E.J. (2001) Is the Export-Led Growth Hypothesis Valid for Developing Countries? A Case Study of Costa Rica. University of Sussex, Falmer and Universidad de Carabobo, Venezuela, New York and Geneva.

[28] Sentsho, J. (2002) Export Revenues as Determinants of Economic Growth: Evidence from Botswana. The University of Botswana, Gaborone.

[29] Helleiner, G.K. (1986) Outward Orientation, Import Instability and African Economic Growth: An Empirical Investigation. In: Theory and Reality in Development, Macmillan, London, 139-153. https://doi.org/10.1007/978-1-349-18128-5 9

[30] Fosu, A.K. (1990) On Export Composition and the Impact Exports on Economic Growth of Developing Countries. Economic Letters, 8, 64-68.

https://doi.org/10.1016/0165-1765(90)90183-2

[31] Kibria, G. and Hossain, S. (2020) Does Export Affect the Economic Growth? An Empirical Investigation for Bangladesh. American Journal of Economics and Business Management, 3, 219-226.

[32] Bhagwati, J.N. (1988) Poverty and Public Policy. World Development, 16, 539-555. https://doi.org/10.1016/0305-750X(88)90184-2

[33] Krugman, P. (1994) Defining and Measuring Productivity. The Age of Diminishing Expectations.

[34] Dimonso, R.L. and Utonga, D. (2019) Nexus between Export and Economic Growth in Tanzania. International Business \& Economics Studies, 1, 95.

https://doi.org/10.22158/ibes.v1n2p95

[35] Twumasi-Ankrah, S. and Wiah, E.N. (2016) Testing for Long-Run Relation between Economic Growth and Export Earnings of Cocoa in Ghana Using Co-Integration Techniques. Ghana Mining Journal, 16, 89-95. https://doi.org/10.4314/gmj.v16i1.11

[36] Owusu, E.L. (2018) Primary Commodity Export and Economic Growth Nexus: The Case of Ghana. Research Journal of Economics, 2, 1.

[37] Khan, R.E.A. and Gill, A.R. (2009) Crowding Out Effect of Public Borrowing: A Case of Pakistan. The Islamia University of Bahawalpur, Bahawalpur, MPRA Paper, 16292. http://mpra.ub.uni-muenchen.de/16292

[38] Engle, R. and Granger, C. (1987) Co-Integration and Error-Correction: Representation, Estimation and Testing. Econometrica, 55, 251-276. https://doi.org/10.2307/1913236

[39] Johansen (1988) Statistical Analysis of Cointegration Vectors. Journal of Economic Dynamics and Control, 12, 231-254. https://doi.org/10.1016/0165-1889(88)90041-3 